\title{
Entry mode deviation: a behavioral approach to internalization theory
}

Article

Accepted Version

Elia, S., Larsen, M. M. and Piscitello, L. (2019) Entry mode deviation: a behavioral approach to internalization theory. Journal of International Business Studies, 50 (8). pp. 13591371. ISSN 1478-6990 doi: https://doi.org/10.1057/s41267019-00235-7 Available at https://centaur.reading.ac.uk/81826/

It is advisable to refer to the publisher's version if you intend to cite from the work. See Guidance on citing.

To link to this article DOI: http://dx.doi.org/10.1057/s41267-019-00235-7

Publisher: Palgrave Macmillan

All outputs in CentAUR are protected by Intellectual Property Rights law, including copyright law. Copyright and IPR is retained by the creators or other copyright holders. Terms and conditions for use of this material are defined in the End User Agreement.

\section{www.reading.ac.uk/centaur}

\section{CentAUR}

Central Archive at the University of Reading

Reading's research outputs online 


\title{
ENTRY MODE DEVIATION:
}

\section{A BEHAVIORAL APPROACH TO INTERNALIZATION THEORY}

\author{
Stefano Elia, DIG-Politecnico di Milano \\ Marcus Moller Larsen, Copenhagen Business School \\ Lucia Piscitello, University of Reading \& Politecnico di Milano
}

\begin{abstract}
We explore when and why decision makers choose international entry modes (e.g., hierarchies or markets) that deviate from internalization theory's predictions. By applying a cognitive perspective on entry mode decision making, we propose that the performance of prior international activities influences decision makers' behavior in different ways than assumed in internalization theory. More specifically, due to a representativeness bias, underperforming (overperforming) past ventures influence the decision to change (continue using) the previous entry mode choice, which may result in an entry mode deviation. In addition, the propensity to deviate from theoretical predictions is stronger when the experience is recent and/or salient due to an availability bias. In conclusion, we argue that internalization theory can benefit from incorporating more systematically important behavioral assumptions on how firms enter international markets. In so doing, we contribute to the recent conversation on how variations in human behavior influence internalization theory.
\end{abstract}

Keywords: Entry mode; deviation from prediction; internalization theory; bounded rationality; cognitive bias.

Acknowledgements: We thank the JIBS Special Issue Editorial Team, the anonymous reviewers, the participants at the JIBS Special Issue Workshop in Minneapolis, and Jean-Francois Hennart for their comments and suggestions that significantly improved this paper. 


\section{INTRODUCTION}

The vast amount of internalization literature that focuses on the choice of foreign entry mode clearly shows that certain types of antecedents (e.g., market imperfections, asset specificity, uncertainty) favor certain modes of entry (i.e., hierarchical or market modes of entry; for reviews see Zhao et al., 2004; Brouthers \& Hennart, 2007). Moreover, the extant research finds that foreign entry modes that do not comply with these theoretical predictions are generally associated with suboptimal selection and performance-deteriorating consequences (e.g., Brouthers, 2002; Elia et al., 2014; Lu and Hébert, 2005).

Notwithstanding the performance implications of theoretical deviations, decision makers do not always behave as internalization theory suggests. Recent research indicates that the processes surrounding decisions to enter foreign markets are widely idiosyncratic, and often based on intuition and heuristics (e.g., Aharoni et al., 2011; Maitland \& Sammartino; 2015; Schubert et al., 2018). Moreover, they do not necessarily match the quasi-rational calculative approaches described in the internalization literature (Buckley et al., 2007).

In this article, we explore the antecedents of entry mode decisions that deviate from the predictions made by internalization theory (i.e., entry mode deviations). In particular, we focus on the role of experience from previous foreign ventures. While the role of international experience in entry mode decisions has received a great deal of attention (Brouthers \& Hennart, 2007), the results remain ambiguous. International experience is generally expected to reduce uncertainty and, therefore, increase the likelihood of market-based entry modes, such as outsourcing and exporting (Zhao et al., 2004). At the same time, more knowledge of foreign markets and operations is associated with entry modes involving greater foreign commitment, such as wholly owned 
subsidiaries (Chi \& Mcguire, 1996; Johanson \& Vahlne, 1977; Vahlne and Johanson, 2017). Hence, international experience can also drive hierarchical entry modes.

Internalization theory assumes that the choice of entry mode should reflect market imperfections to mitigate potential hazards and opportunistic behavior, and to foster knowledge transfer (e.g., Hennart, 1982; Verbeke \& Greidanus, 2007). However, rather than assuming that managers act rationally to maximize the utility of the multinational enterprise (for a recent review, see Aharoni et al., 2011), we use insights from behavioral economics and psychology to explain how bounded rationality and, in particular, cognitive limitations and heuristics may prompt decision makers to make decisions that result in entry mode deviations (Foss and Weber, 2016; Kahneman \& Tversky, 1979; Thaler, 1991, 2016). More specifically, we argue that the outcomes of previous experiences may lead to entry mode decisions based on heuristics and systematic biases, irrespective of the predictions of international theory, which may lead to entry mode deviations. In particular, entry mode decisions may result in deviations when decision makers are influenced by a representativeness bias and react to previous underperformance (overperformance) experience by changing (continue using) the previous entry mode. Moreover, when past experiences are recent and/or salient, decision makers become subject to an availability bias, which also increases the likelihood of deviations.

We believe that our article carries important implications for future research. By augmenting internalization theory with a behavioral perspective, we propose a novel take on the entry mode discussion. While existing research has emphasized the performance-deteriorating consequences of deviating decisions, we argue that the outcome of the firm's previous international experience may foster important biases that yield different entry mode decisions. Accordingly, we draw on behavioral economics to explain how decision makers often make 
judgements under uncertainty based on heuristics that lead to systematic biases (Thaler, 2016).

Thus, we contribute to the broader discussion of how cognitive biases and heuristics can lead to a more profound understanding of the role of the individual in MNEs' decision-making processes. In so doing, we add to the emerging stream of international business research that questions whether managers actually behave as internalization theory suggests, and we explain how cognitive factors and limitations influence managers' preferences and cognition when making internationalization decisions (Buckley et al., 2007; Maitland \& Sammartino, 2015; Schubert et al., 2018).

\section{THEORETICAL FRAMEWORK}

\section{Entry mode deviation}

According to internalization theory, decision makers select internalized modes of international entry "when markets in intermediate products are imperfect [because] there is an incentive to bypass them creating an internal market" (Buckley \& Casson, 1976: 33). As complex, specific, and uncertain activities are prone to opportunistic behavior and moral hazards in international markets, they are argued to be most efficiently organized within a hierarchy (Brouthers, 2002; Hennart, 1977; 1982).

While internalization theory's predictions regarding entry modes have largely been empirically validated (Hennart \& Brouthers, 2007; Zhao et al., 2004), there is notable evidence of firms choosing entry modes that deviate from those predictions. Brouthers (2002), for instance, finds that many firms select entry modes that do not comply with internalization theory, and that firms that do comply generally perform better than firms that make other mode choices. Elia et al. (2014) find a positive relationship between entry modes that are aligned with internalization theory and performance, although with an asymmetric effect based on the predicted entry mode and the 
type of performance considered. Relatedly, Lu \& Hébert (2005) find that many joint ventures are established using equity modes not aligned with internalization theory, and that such ventures are more likely to be terminated than those with aligned equity modes.

\section{---Table 1 around here---}

We focus on cases in which decision makers select entry modes that deviate from the predictions of internalization theory. A simple conceptualization of this focus is presented in Table 1, where firms may either comply or deviate from internalization theory's predictions. ${ }^{1}$ By selecting a theoretically compliant hierarchical mode (e.g., a wholly owned subsidiary) in the presence of substantial market imperfections, decision makers choose an internalized governance structure that both protects the firm's assets from opportunistic behavior and moral hazards (Buckley \& Casson, 1976; Hennart, 1977), and increases opportunities for knowledge transfer (Hennart, 1982; Kogut \& Zander, 1993). Relatedly, when market imperfections are low, decision makers may benefit from establishing a theoretically compliant market mode (e.g., exporting or outsourcing) in which they can exploit the benefits of external markets, such as lower production costs, access to external knowledge, and competition (Doh, 2005).

However, whenever decision makers select entry modes that deviate from internalization theory, the activities are potentially subject to higher performance deteriorating consequences than activities governed by theoretically compliant entry modes. If decision makers select externally oriented entry modes (e.g., exporting, outsourcing) in conditions characterized by high market imperfections, they deviate from internalization theory (i.e., deviating market modes). In these situations, the probability of hold-up, opportunistic behavior, and moral hazards in international

\footnotetext{
${ }^{1}$ For the sake of theoretical simplicity, we treat the entry-mode choice as a dichotomous choice between market and hierarchical modes. In practice, the range of entry-mode choices is more complex and multifaceted.
} 
markets increases (Buckley and Casson, 1976; Hennart, 1977, 1982). Similarly, in contexts characterized by fewer market imperfections and lower transaction costs, the establishment of activities through costly hierarchical operations, such as wholly owned entities, deviate from internalization theory (i.e., deviating hierarchical modes). In such cases, the decision makers only focus on internal sources of knowledge, fail to exploit market benefits, and incur inefficiency traps (Williamson, 2008), internal learning myopia (Levinthal \& March, 1993), and the "not invented here" syndrome (Katz \& Allan, 1982).

\section{Bounded rationality, heuristics, and bias in entry mode deviations}

We explore how previous international experiences influence the adoption of entry modes that deviate from the predictions of internalization theory. As mentioned, market imperfections and transaction costs are viewed as key explanations of the market or hierarchical entry mode choice (e.g., Albertoni et al., 2018). In this respect, internalization theory suggests that international experience reduces perceived foreign environmental and transactional uncertainty, thereby lowering the cost of using the market (Anderson \& Gatignon, 1986; Aulakh, Kotabe, \& Sahay, 1996; Benito \& Gripsrud, 1992). For example, country-specific experience has been suggested to reduce decision makers' perceptions of external uncertainties, such as their perceptions of institutional and cultural distance between the home and host countries (Henisz \& Macher, 2004; Tihanyi, Griffith, \& Russell, 2005).

At the same time, evolutionary and real-options perspectives on internationalization emphasize that the reduction in uncertainty associated with international experience leads firms towards greater foreign commitment and hierarchical choices (e.g., Chi \& Mcguire, 1996; Johanson \& Vahlne, 1977; Vahlne and Johanson, 2017). Related empirical research shows that 
experienced MNEs are more likely to set up high-equity operations abroad (e.g., Gomes-Casseres, 1989; Padmanabham \& Cho, 1996). ${ }^{2}$

The majority of these perspectives incorporate a rather simplistic view of decision makers and their entry mode decisions. For example, internalization theory assumes a quasi-rational decision maker with calculative abilities that enable him or her to make economically sound choices (Buckley et al., 2007). Although this theory assumes that decision makers are "intendedly rational, but only limited so" (Simon, 1947: xxiv), the majority of studies on international experience and entry modes only incorporate bounded rationality as an assumption to explain opportunism and incomplete contracts, while they largely ignore how cognitive limitations permeate decision-making processes (see Brouthers \& Hennart, 2007; Maitland \& Sammartino, 2015). For example, Verbeke (2003) uses the concept of bounded rationality to explain how such factors as limited information-processing abilities lead to certain types of governance modes in international markets, but he does not discuss the cognitive processes underlying this selection. ${ }^{3}$ Larsen et al. (2013) show how organizational complexity undermines decision makers' abilities to process relevant information in order to accurately estimate the costs of foreign expansion, but they ignore the more profound, cognitively constrained processes that shape these decisions. As Aharoni (2010: 101) suggests, "in their search for elegance and rigor, IB researchers ignored the rich evidence on psychological aspects of decision making, the complexity of decision making under uncertainty and the accumulation of commitments."

\footnotetext{
${ }^{2}$ In a meta-analysis of foreign entry modes, Zhao et al. (2004) find that the effect of international experience on entry modes varies significantly depending on the measurement approach, with host-country experience and percentage of international assets exhibiting greater effects.

${ }^{3}$ However, Verbeke \& Greidanus (2009) attempted to incorporate some cognitive limitations in the managerial theory by using the term "bounded reliability".
} 
To understand entry mode deviations, we incorporate important behavioral assumptions on entry mode decisions making. We assume that decision makers typically recognize only a partial number of possible decision alternatives when entering foreign markets, and that they evaluate those alternatives subjectively and incoherently (Simon, 1955). This view on bounded rationality implies that decision makers not only suffer from limited information-processing capacity, as described in extant internalization theory, but also suffer from a number of biases and cognitive limitations that restrain rational intentions and lead to judgements based on heuristics derived from experience (e.g., Tversky \& Kahneman, 1974; Thaler, 2016). Decision makers tend to reduce the complexity of some tasks — such as selection of a foreign entry mode — by relying on a limited number of heuristic principles. While these heuristics are useful for simplifying judgement tasks, they can also lead to irrational choices and/or systematic errors. For instance, when a person tries to estimate the distance to an object, that assessment is likely to be biased by the clarity with which the object can be observed-distance is often overestimated when visibility is poor (with blurred contours) and underestimated when visibility is good (with clearer contours) (Tversky \& Kahneman, 1974).

The foreign investment decision is one of the processes that may be subject to heuristics and biases. For example, decision makers may associate different risk propensities with foreign ventures, especially when involving the internationalization of R\&D (Schubert et al., 2018). In addition, managers may have heterogeneous mental models and sense-making abilities that influence how they establish foreign ventures (Maitland \& Sammartino, 2015). Moreover, as decision makers have idiosyncratic personal social networks, psychic distance perceptions, and past experiences, their perceptions of uncertainty differ (Aharoni et al., 2011). 
We build on these contributions to argue that international experience may systematically bias decision makers away from the dominant rationality assumptions underlying internalization theory, thereby making entry mode deviations more likely. In the next section, we develop a set of propositions on how international experience may prompt certain cognitive biases that reduce the likelihood of selecting the entry modes predicted by internalization theory. We focus on firms' experience with international activities that performed either above or under expectations, and associate those experiences with two main cognitive biases (Tversky \& Kahneman, 1974): ${ }^{4}$ (i) representativeness bias, which refers to the idea that decisions tend to be based on how similar a situation is to a situation encountered in the past (or how typical or representative the case in question is); and (ii) availability bias, which refers to the idea that judgements are made based on examples available in decision makers' minds (especially the most salient and/or more recent examples).

\section{PROPOSITION DEVELOPMENT}

\section{Representativeness bias}

The performance of foreign ventures in the past may have important consequences for future decision-making processes. The perception of future options is often based on the perceived value of the resources that have been gained or lost during previous experiences (Vahlne and Johanson, 2017). For example, a recent contribution by Albertoni et al. (2018) shows that only firms that are able to identify the organizational practices that were responsible for the success or failure of the past entry modes improve the growth outlook for future ventures. They argue that past performance fosters a process of "mindful" learning that leverages not only experiential knowledge (i.e.,

\footnotetext{
${ }^{4}$ Although we only highlight two main biases, scholars in cognitive psychology have identified a number of different heuristics and biases that individuals are subject to when making judgements under uncertainty (e.g., Hogarth, 1980; Tversky \& Kahneman, 1973, 1974).
} 
improvements in extant routines for the configuration of foreign business activities, such as the abilities to interact with external players or to manage foreign subsidiaries) but also organizational knowledge (i.e., the transfer of the best practices created by subsidiaries and suppliers to the organization).

Here we adopt a different perspective based on heuristics and biases rather than on rational learning. In this regard, we argue that the underperformance or overperformance of past ventures may prompt the choice of entry modes that deviate from internalization theory's predictions. We suggest that decision makers will tend to associate a venture's performance with its entry mode and use this as a benchmark for the next entry mode choice. While a rational decision maker would evaluate the new entry decision based on an objective assessment of the market imperfections and trade-offs between production and transaction costs, we propose that a decision maker constrained by bounded rationality will likely be influenced by cognitive biases and heuristics stemming from the outcomes of previous experiences, which might prompt the adoption of deviating choices (e.g., Thaler, 2016).

More specifically, we argue that past performance is likely to induce a cognitive representativeness bias "in which probabilities are evaluated by the degree to which A is representative of B, that is, by the degree to which A resembles B" (Tversky \& Kahneman, 1974: 1124). In other words, the representativeness bias causes decision makers to overestimate the degree to which a situation or sample is representative of a more general population. Moreover, it causes decision makers to overestimate the extent to which the past is representative of the present and whether solutions used in the past will be valuable for future challenges (Kahneman \& Tversky, 1973; Tversky \& Kahneman, 1974). 
The extant research shows that the representativeness bias has important consequences for strategic decision making. For example, in a study on investment decision making among Chinese investors, Chen et al. (2007) find that inventors largely believe that past returns are fully representative of what they can expect in the future, while they ignore other investment characteristics. Investors have also been found to misattribute a company's positive characteristics (e.g., high-quality products, capable managers, high expected growth) as characteristics of a good investment (Lakonishok, Shleifer, \& Vishny, 1994). As such, vivid anecdotal information may cause a representativeness bias by drawing decision makers' attention away from other types of information.

To exploit these insights in our context, we suggest that if decision makers assess that a given entry mode $i$ is negatively (positively) associated with performance, they are likely to generalize from that experience and conclude that entry mode $i$ is "bad" ("good"). For example, if an externalized venture has been subject to a serious hold-up situation that consequently necessitated costly legal procedures, decision makers may associate this adverse experience with the chosen entry mode and, hence, decide to change the mode of entry for future ventures. Likewise, if an international internalized venture turns out to be a particularly valuable source of knowledge creation for the MNE, decision makers may associate this positive performance with the chosen entry mode and, thus, decide to continue using that mode of entry in the future. As such, we argue that decision makers will have a propensity to ascribe, at least part of, the past negative (positive) performance to that specific entry mode and, therefore, be biased against (towards) that mode, regardless of the predictions found in internalization theory. Assuming that decision makers interpret and adjust their behaviors according to their experiences (March \& Simon, 1958), we thus suggest that they are more likely to change entry modes due to a 
representativeness bias when they have experienced underperformance and to continue using entry modes in cases of good performances.

Accordingly, decision makers are more likely to select a deviating entry mode whenever the decision to continue using or to change the entry mode is at odds with the predicted entry mode. This leads to the following proposition:

Proposition 1: Decision makers are more likely to continue using a past entry mode " $i$ " if " $i$ " was associated with overperformance, and to choose a different entry mode " $j$ " if " $i$ " was associated with underperformance (thereby deviating from internalization theory if the predicted modes are " $j$ " and " $i$ ", respectively).

Table 2 illustrates and simplifies the implications of the first proposition. Namely, the table shows the relationships among: (i) past performance (underperformance or overperformance); (ii) past entry mode (market or hierarchy); and (iii) predicted entry mode (market or hierarchy). If the performance of past ventures was below expectations, deviation occurs when the predicted entry mode and the entry mode that was perceived as responsible for previous underperformance are the same. Thus, deviation occurs when the prediction suggests a market entry mode and the past underperformance was associated with a market entry mode (cell 1: deviating hierarchical mode), or when the prediction is a hierarchical entry mode and the past underperformance was associated with a hierarchical entry mode (cell 4: deviating market mode). Conversely, if the predicted entry mode and the entry mode that was perceived as responsible for the negative past performance differ, the selected entry mode will comply with the prediction of internalization theory, thereby leading to a compliant market mode (cell 3) or a compliant hierarchical mode (cell 2). Likewise, when past performance was above expectations, deviation occurs only in cases of dissimilarity between the predicted entry mode and the entry mode that was associated with past 
overperformance. Indeed, deviation occurs when the prediction is a market entry mode and the past overperformance was associated with a hierarchical entry mode (cell 7: deviating hierarchical mode), or when the prediction suggests a hierarchical entry mode and the past overperformance was associated with a market entry mode (cell 6: deviating market mode). In the two other cases, where the predicted entry mode and the entry mode associated with the past overperformance are the same, the selected entry mode will comply with the prediction of internalization theory, thereby leading to a compliant market mode (cell 5) or to a compliant hierarchical mode (cell 8).

\section{Availability bias}

While Proposition 1 suggests that the performance of past ventures may motivate decision makers to select entry modes that deviate from internalization theory, we also acknowledge that international experience is a multifaceted phenomenon involving a variety of dimensions (Argote \& Todorova, 2007). For example, an underperforming venture may be a recent or distant memory, it may have had serious or trivial consequences for the firm, and that underperformance may have occurred numerous times or only once. To incorporate this heterogeneity into our theory, we explore the impact of the availability of judgment heuristics, which refers to the ease with which certain instances and occurrences (i.e., the outcomes of previous experiences) can be recalled.

Decisions makers with an availability bias are likely to make decisions based on the retrievability of similar cases (Tversky \& Kahneman, 1974). Assuming that decision makers' past experiences influence their perceptions of future events, the availability bias suggests that those situations that are either more salient or more recent are more available or easily recalled in connection with current decision making (Tversky \& Kahneman, 1973; Bazerman, 1994). As such, the availability bias arises when the retrievability of an instance is affected by factors other than the probability of an instance occurring (Tversky \& Kahneman, 1974). 
We first explore the question of salience, which concerns the extent to which the decision maker is affected by the consequences of the past event. The availability bias suggests that individuals tend to recall events that are easy to remember due to their strong emotional impact or high familiarity (e.g., house fires or airplane crashes), even if such events are rare from a probabilistic point of view. Research in strategic management and international business shows that the availability bias may influence strategic decision-making processes. While exploring the consequences of foreign language use in organizational settings, Volk et al. (2014) discuss how an availability heuristics can lead to judgmental biases, such as the underestimation of political, social, and economic risks in foreign markets, based on an experience of enduring stability in familiar markets. Relatedly, $\mathrm{Ng}$ et al. (2009) discuss how the availability bias leads managers to develop a "self-centered" view of competition that eventually blinds them from the competitive perceptions of their value-chain customers.

The application of these insights to our context leads us to expect a decision maker to be more likely to change entry modes if the underperformance of a past foreign venture was highly salient (e.g., caused the subsidiary to be shut down or re-shored; Albertoni et al., 2017) rather than trivial (e.g., a minor loss; Larsen, 2016). For example, a decision maker would presumably put more emphasis on a negative experience derived from a serious hold-up situation with an opportunistic partner than it would on a negative experience with internalized inefficiency traps. The consequences of a serious hold-up situation including costly legal procedures would be assessed as more salient than the trivial consequences of a suboptimal use of internal resources. Consequently, the decision maker would be more likely to be biased towards hierarchical modes of entry in the future (as a response to the perceived salient underperformance of an externalized 
mode) than towards market (as a response to perceived trivial underperformance of an internalized mode).

Conversely, we expect decision makers to be more likely to continue using an entry mode when past overperformance was highly salient (e.g., a subsidiary being upgraded to a center of excellence; see Frost et al., 2002) rather than trivial (e.g., an incremental increase on the expected sales). For example, a decision maker would perceive a situation where an external partner delivers higher quality at a lower costs as more salient than an effective internalized control of firm assets. Thus, the decision maker would be more biased towards externalized modes of entry (as a response to the perceived salient overperformance of an externalized mode) than towards hierarchy (as a response to perceived trivial overperformance of an internalized mode).

In general, we emphasize that the salience of the performance of a past venture increases the ease with which that venture can be brought to mind. As a salient venture is more easily recalled, the decision maker assigns greater subjective probability to the likelihood that the entry mode affected that venture's performance. Therefore, we argue that whenever the decision maker has experience with several previous entries in different modes, but the underperforming (overperforming) ventures in mode $i$ are more salient, the decision maker is more likely to change (continue using) mode $i$ and, hence, deviate from the prediction that indicates mode $i(j)$. If the prediction is market (hierarchy) and that entry mode was responsible for memorable negative performance in the past, the probability of adopting a deviating hierarchical mode (deviating market mode) in cell 1 (4) of Table 2 will be higher due to availability bias. Likewise, the availability bias will increase the probability of adopting a deviating hierarchical mode (deviating market mode) in cell 7 (6) of Table 2 if the prediction points to a market (hierarchical) entry mode 
and that entry mode was perceived as responsible for memorable positive performances in the past. Accordingly, our second proposition is as follows:

Proposition 2: The higher the salience of an overperforming (underperforming) past entry mode " $i$ " the higher the likelihood of decision makers continuing to use entry mode " $i$ " (choose a different entry mode “ $j$ ”), thus resulting in a deviation from internalization theory if the predicted entry mode is " $j$ " (" $i$ ”).

The retrievability of an event is also likely to be stronger when the experience is recent, as a recent event comes more easily to mind than an older one. Put simply, a person will ascribe a higher probability to having a car accident after having recently seen such an event (Tversky \& Kahneman, 1974). As such, the availability bias also points to the pervasive human tendency to judge the probability of an event based on whether similar experiences are recent or old. For instance, Chen et al. (2007) suggest that investors' perceptions about the future are mainly affected by the returns on the most recent (rather than the oldest) investments. In a study on the impact of past events on the perception of products by consumers in historically connected markets, Gineikiene and Diamantopoulos (2017) similarly argue that recent events will be more impactful as they are more attention-grabbing and easier to be accessed.

We build on this insight to suggest that when an underperforming entry occurred in the recent past, the decision maker will perceive it as more intensive, which will lead to a higher likelihood of a change in entry mode and, thereby, an entry mode deviation. For example, an MNE having a negative experience with an international venture displaying a suboptimal usage of internal resources a year ago may have a larger impact on future decision-making than a serious hold-up situation in an externalized international venture occurring five years ago. Consequently, the decision maker may be more biased towards market modes of entry in the future (as a response 
to the underperformance of a hierarchical mode being perceived as recent) than towards hierarchical modes of entry (as a response to the underperformance of an externalized mode being perceived as old). Conversely, a decision maker would likely perceive a recent situation of effective internalized control of firm asset as more important than an old case where an external partner delivers higher quality at a lower costs. The decision maker thus would be more biased towards internalized modes of entry (as a response to the overperformance of an internalized mode being perceived as recent) than towards hierarchy (as a response to the overperformance of an externalized mode being perceived as old).

As such, if the predicted market (hierarchical) entry mode was associated with negative performance in the recent past, the probability of adopting a deviating hierarchical (deviating market) mode in cell 1 (4) of Table 2 will be higher due to availability bias. Likewise, if the predicted market (hierarchical) entry mode was responsible for positive performance in the recent past, the probability of adopting a deviating hierarchical (deviating market) mode in cell 7 (6) of Table 2 will be higher due to availability bias. Accordingly, our third proposition is the following:

Proposition 3: The more recent the overperforming (underperforming) past entry using mode " $i$," the greater the likelihood that decision makers continue to use entry mode " $i$ " (choose a different entry mode “ $j$ ”), thus resulting in a deviation from internalization theory if the predicted entry mode is " $j$ " (" $i$ ").

\section{DISCUSSION}

In this article, we have discussed when and why decision makers may choose entry modes that deviate from the predictions of internalization theory. The extant research in internalization theory tends to classify the selection of such entry modes as suboptimal and performance deteriorating (e.g., Brouthers, 2002). We have attempted to augment internalization theory with behavioral 
assumptions based on heuristics and cognitive biases. In so doing, we propose that past international performance invokes a cognitive representativeness bias that increases decision makers' propensities to select entry modes that deviate from the predictions of internalization theory. We also argue that the heterogeneity of international experience in terms of salient experiences and chronological retrievability (timing) influences the relationship between past performance and entry mode deviations.

We contribute to research on internalization theory by: 1) more systematically emphasizing the behavioral aspects of entry mode decisions and 2) unravelling the different roles of international experience.

First, while internalization theory explains the economic rationale for choosing one entry mode over another, we emphasize that the reality of international entry mode decision making is subject to cognitive biases and heuristics. By shedding light on the behavioral antecedents of international decision making (e.g., Buckley et al., 2007; Sammartino \& Maitland, 2015; Schubert et al., 2018), we contribute to internalization theory by explaining how different types of cognitive limitations and biases may explain why some firms and their decision makers are more inclined to select entry modes that fit the theoretical expectations while others do not. Accordingly, we encourage researchers to continue exploring the bounded-rationality assumption of internalization theory by emphasizing how behavioral characteristics drive variation in entry mode selection (see Foss \& Weber, 2016). In addition, by stressing the role of past events in shaping the cognitive frames and biases that affect present entry mode choices, we suggest that bounded rationality is not a static construct. Instead, it evolves through previous experiences and their outcomes. Indeed, as shown by Buckley et al. (2007) for location choices, we explain how entry mode choices result from dynamic decision-making processes. 
In this respect, it is important to emphasize that we only offer a selective account of the potential cognitive biases and heuristics that may influence decision makers as they enter new international markets. Our primary intention is to initiate a discussion of how different systematic biases that have largely been overlooked by the international business community may lead to firm behavior that deviates from the behavior predicted by internalization theory. A number of other cognitive limitations have been discussed in the literature. As suggested by Thaler (2016), human judgement diverges from rational expectations in a multitude of interesting ways, each of which offers a possibility to provide useful insights into economic behavior.

Future studies could also investigate whether a specific bias can have different effects on rational decision processes in various categories of companies (e.g., family firms, SMEs, SOEs) in which decision makers are likely to show different behavioral attitudes. They might also analyze the cognitive biases affecting the entry mode choice when two or more individuals jointly contribute to a decision-making process (e.g., in top management teams) (Chi, 2015) or the interaction between cognitive mechanisms and culture (Fitzsimmons et al., 2017). Another fruitful avenue would be to explore the extent to which deviation varies with the type of entry mode predicted. For instance, in cases of activities characterized by relatively low transaction costs, cost inefficiencies may arise if (theoretically deviating) hierarchical solutions are adopted (e.g., Williamson, 2008), while activities with higher transaction costs are more prone to opportunistic behavior and hold-up if established through (theoretically deviating) externalized market solutions (Buckley \& Casson, 1976; Hennart, 1977, 1982). Thus, decision makers who are influenced by a loss-aversion bias may perceive the potential capture of valuable intellectual property or knowledge by a foreign outsourcing partner as more harmful than the potential loss of efficiency associated with keeping simple production in-house. Relatedly, decision makers may assess that 
the potential loss associated with hold-up in a foreign country is worse than the potential loss associated with making costly internal investments. When this is the case, managers might be less motivated to deviate from the predicted entry mode if it favors hierarchies. This logic is supported by prospect theory, which shows that decision makers tend to be more biased toward loss aversion than potential gains (Tversky \& Kahneman, 1981).

Second, we contribute to recent discussions on the relationship between international experience and entry mode decisions (Brouthers \& Hennart, 2007). Entry mode research has noted the lack of clarity regarding whether firms "merely consider the frequency with which specific modes were chosen previously" or "take into account the ex post performance of prior choices and hence learn from them" and, in that case, "from which types of experiences do they learn more" (Hennart \& Slangen, 2015: 118). In this respect, we disentangle the important roles of cognitive biases and judgmental heuristics stemming from the performance of past ventures, their timing, and their salience. Research has emphasized such issues as how prior international experience not only assists firms in accumulating capabilities that can be adopted across several geographical areas (Schwens et al., 2018), but also helps reduce operational difficulties (Chang, 1995; Delios \& Beamish, 2001; Gao et al., 2008; Perkins, 2014) and speeds up the pace of sequential entries (Gao \& Pan, 2010). However, while much of this research adopts a uniform operationalization of experience in which "more is better", we emphasize the cognitive consequences of basing future decisions on past performance. In this regard, we encourage future research to explore operationalizations of experience other than frequency, such as whether the experience stems from a recent or old venture, or if an experience can be perceived as salient or trivial. As we suggest, a venture that underperformed a few years ago is more likely to affect decision makers' attention than a venture that underperformed ten years ago. Relatedly, underperforming ventures that have 
severe financial consequences are more likely to influence decision-making processes. We also encourage future international business research to continue disentangling the cognitive antecedents and consequences of decision makers' behavior in international markets by adopting a more "micro-based" approach that takes not only the rationality but also the psychological traits of individuals into account. In this regard, we hope our work contributes to a promising conversation in which the human rather than the homus economicus is the one making choices, thereby leading to a study of international business that yields greater explanatory power (Thaler, 2016).

In conclusion, we introduce important behavioral assumptions on how decision makers enter international markets and, more specifically, on why firms may opt for entry modes that deviate from the predictions of internalization theory. While we have studied this idea in the context of international entry mode decisions, we believe that this augmented perspective on internalization theory is generalizable to other contexts in which performance feedback and organizational behavior are relevant, such as strategic alliances, organizational restructuring, and innovation. Likewise, we have focused only on those biases that we consider to be most relevant for understanding deviations from internalization theory's predictions. However, the body of literature on heuristics and biases is large, so other affective biases as well as their interactions (e.g., Livet, 2010; Fairchild, 2014) are likely to also have a significant influence. 


\section{REFERENCES}

Aharoni, Y. (2010). Behavioral elements in foreign direct investments. In: The Past, Present and Future of International Business \& Management (pp. 73-111). Emerald Group Publishing Limited.

Aharoni Y., Tihanyi L., \& Connelly B.L. (2011). Managerial decision-making in international business: A forty-five year retrospective. Journal of World Business, 46, 135-142

Albertoni, F., Elia, S., Massini, S., \& Piscitello, L. (2017). The reshoring of business services: Reaction to failure or persistent strategy?. Journal of World Business, 52(3), 417-430.

Albertoni, F., Elia, S., \& Piscitello, L. (2018). Inertial vs. mindful repetition of previous entry mode choices: Do firms always learn from experience? Journal of Business Research, 2018, forthcoming.

Anderson, E., \& Gatignon, H. (1986). Modes of foreign entry: A transaction cost analysis and propositions. Journal of International Business Studies, 17(3), 1-26.

Argote, L., \& Todorova, G. (2007). Organizational learning. International Review of Industrial and Organizational Psychology, 22, 193.

Aulakh, P. S., Kotabe, M., \& Sahay, A. (1996). Trust and performance in cross-border marketing partnerships: A behavioral approach. Journal of International Business Studies, 27(5), 10051032.

Bazerman, M. H. (1994). Judgement in Managerial Decision Making. New York: Wiley

Benito, G. R., \& Gripsrud, G. (1992). The expansion of foreign direct investments: discrete rational location choices or a cultural learning process?. Journal of International Business Studies, 23(3), 461-476.

Brouthers, K.D., Hennart J-F. (2007). Boundaries of the Firm: Insights from International Entry Mode Research. Journal of Management, 33(3): 395-425.

Brouthers, K. D. (2002). Institutional, cultural and transaction cost influences on entry mode choice and performance. Journal of International Business Studies, 33(2), 203-221.

Buckley, P. J., \& Casson, M. (1976). Future of the multinational enterprise. London: Macmillan.

Buckley, P. J., Devinney, T. M., \& Louviere, J. J. (2007). Do managers behave the way theory suggests? A choice-theoretic examination of foreign direct investment location decisionmaking. Journal of International Business Studies, 38(7), 1069-1094.

Chang, S. J. (1995). International expansion strategy of Japanese firms: Capability building through sequential entry. Academy of Management Journal, 38(2), 383-407.

Chen, G., Kim, K. A., Nofsinger, J. R., \& Rui, O. M. (2007). Trading performance, disposition effect, overconfidence, representativeness bias, and experience of emerging market investors. Journal of Behavioral Decision Making, 20(4), 425-451.

Chi, T. (2015). Commentary: Internalization theory and its relation to RBV and TCE. Journal of World Business, 50, 634-636.

Chi, T., \& McGuire, D. J. (1996). Collaborative ventures and value of learning: Integrating the transaction cost and strategic option perspectives on the choice of market entry modes. Journal of International Business Studies, 27(2), 285-307.

Delios, A. \& Beamish, P.W. (2001). Survival and profitability: the roles of experience and intangible assets in foreign subsidiary performance. The Academy of Management Journal, 44(5): 1028-1038.

Doh, J. P. (2005). Offshore outsourcing: Implications for international business and strategic management theory and practice. Journal of Management Studies, 42(3), 695-704. 
Elia, S., Caniato, F., Luzzini, D., \& Piscitello, L. (2014). Governance choice in global sourcing of services: the impact on service quality and cost saving performance. Global Strategy Journal, 4(3), 181-199.

Fairchild, R. (2014): Emotions in the Financial Markets. In: Baker and Ricciardi, eds., Investor Behavior: The Psychology of Financial Planning and Investing, Wiley.

Fitzsimmons, S. R., Liao, Y., \& Thomas, D. C. (2017). From crossing cultures to straddling them: An empirical examination of outcomes for multicultural employees. Journal of International Business Studies, 48(1), 63-89.

Foss, N. J., \& Weber, L. (2016). Moving opportunism to the back seat: Bounded rationality, costly conflict, and hierarchical forms. Academy of Management Review, 41(1), 61-79.

Frost, T. S., Birkinshaw, J. M., \& Ensign, P. C. (2002). Centers of excellence in multinational corporations. Strategic Management Journal, 23(11), 997-1018.

Gao, G.Y., Pan, Y., Lu, J. \& Tao, Z. (2008). Performance of multinational firms' subsidiaries: influence of cumulative experience. Management International Review, 48(6), 749-768.

Gao, G. Y., \& Pan, Y. (2010). The pace of MNEs' sequential entries: Cumulative entry experience and the dynamic process. Journal of International Business Studies, 41(9), 1572-1580.

Gineikiene, J., \& Diamantopoulos, A. (2017). I hate where it comes from but I still buy it: Countervailing influences of animosity and nostalgia. Journal of International Business Studies, 48(8), 992-1008.

Gomes-Casseres, B. (1989). Ownership structures of foreign subsidiaries: Theory and evidence. Journal of Economic Behavior \& Organization, 11(1), 1-25.

Henisz, W. J., \& Macher, J. T. (2004). Firm-and country-level trade-offs and contingencies in the evaluation of foreign investment: The semiconductor industry, 1994-2002. Organization Science, 15(5), 537-554.

Hennart, J. F., \& Slangen, A. H. (2015). Yes, we really do need more entry mode studies! A commentary on Shaver. Journal of International Business Studies, 46(1), 114-122.

Hennart, J. F. (1977). A theory of foreign direct investment (Doctoral dissertation, University of Maryland, College Park.).

Hennart, J. F. (1982). A theory of multinational enterprise. Ann Arbor, MI: University of Michigan Press.

Johanson, J., \& Vahlne, J. E. (1977). The internationalization process of the firm-a model of knowledge development and increasing foreign market commitments. Journal of International Business Studies, 8(1), 23-32.

Kahneman, D., \& Tversky, A. (1973). On the psychology of prediction. Psychological Review, 80(4), 237.

Kahneman, D., \& Tversky, A. (1979). Prospect theory: An analysis of decision under risk. Econometrica: Journal of the Econometric Society, 263-291.

Katz, R., \& Allen, T. J. (1982). Investigating the Not Invented Here (NIH) syndrome: A look at the performance, tenure, and communication patterns of $50 \mathrm{R} \& \mathrm{D}$ Project Groups. $R \& D$ Management, 12(1), 7-20.

Kogut, B., \& Zander, U. (1993). Knowledge of the firm and the evolutionary theory of the multinational corporation. Journal of International Business Studies, 24(4), 625-645.

Lakonishok, J., Shleifer, A., \& Vishny, R. W. (1994). Contrarian investment, extrapolation, and risk. The Journal of Finance, 49(5), 1541-1578.

Larsen, M. M. (2016). Failing to estimate the costs of offshoring: A study on process performance. International Business Review, 25(1), 307-318. 
Larsen, M. M., Manning, S., \& Pedersen, T. (2013). Uncovering the hidden costs of offshoring: The interplay of complexity, organizational design, and experience. Strategic Management Journal, 34(5), 533-552.

Levinthal, D. A., \& March, J. G. (1993). The myopia of learning. Strategic Management Journal, 14(S2), 95-112.

Livet, P. (2010). Rational Choice, Neuroeconomy, and Mixed Emotions. Philosophical Transactions of the Royal Society, 36:138, 29-269.

Lu, J. W., \& Hébert, L. (2005). Equity control and the survival of international joint ventures: a contingency approach. Journal of Business Research, 58(6), 736-745.

Maitland, E., \& Sammartino, A. (2015). Decision making and uncertainty: The role of heuristics and experience in assessing a politically hazardous environment. Strategic Management Journal, 36(10), 1554-1578.

March, J. G., \& Simon, H. A. (1958). Organizations. Wiley-Blackwell: New York

Ng, D., Westgren, R., \& Sonka, S. (2009). Competitive blind spots in an institutional field. Strategic Management Journal, 30(4), 349-369.

Padmanabhan, P., \& Cho, K. R. (1996). Ownership strategy for a foreign affiliate: An empirical investigation of Japanese firms. MIR: Management International Review, 45-65.

Perkins, S. E. (2014). When does prior experience pay? Institutional experience and the multinational corporation. Administrative Science Quarterly, 59(1), 145-181.

Schubert, T., Baier, E., \& Rammer, C. (2018). Firm capabilities, technological dynamism and the internationalisation of innovation: A behavioural approach. Journal of International Business Studies, 49(1), 70-95.

Schwens, C., Zapkau, F. B., Brouthers, K. D., \& Hollender, L. (2018). Limits to international entry mode learning in SMEs. Journal of International Business Studies, 49(7), 809-831.

Simon, H. A. 1947. Administrative behavior. Macmillan: New York.

Simon, H. A. (1955). A behavioral model of rational choice. The Quarterly Journal of Economics, 69(1), 99-118.

Thaler, R. H. (1991). The winner's curse: Paradoxes and anomalies of economic life. New York: Free Press.

Thaler, R.H. (2016). Behavioral Economics: Past, Present, and Future. American Economic Review, 106 (7): 1577-1600.

Tihanyi, L., Griffith, D. A., \& Russell, C. J. (2005). The effect of cultural distance on entry mode choice, international diversification, and MNE performance: A meta-analysis. Journal of International Business Studies, 36(3), 270-283.

Tversky, A., \& Kahneman, D. (1973). Availability: A heuristic for judging frequency and probability. Cognitive Psychology, 5(2), 207-232.

Tversky, A. \& Kahneman, D. (1974). Judgment under uncertainty: Heuristics and biases. Science 185, pp. 1124-1131.

Tversky, A., \& Kahneman, D. (1981). The framing of decisions and the psychology of choice. Science, 211(4481), 453-458.

Verbeke, A., \& Greidanus, N. S. (2009). The end of the opportunism vs trust debate: Bounded reliability as a new envelope concept in research on MNE governance. Journal of International Business Studies, 40(9), 1471-1495.

Verbeke, A. (2003). The evolutionary view of the MNE and the future of internalization theory. Journal of International Business Studies, 34(6), 498-504. 
Vahlne, J. E., \& Johanson, J. (2017). From internationalization to evolution: The Uppsala model at 40 years. Journal of International Business Studies, 48(9), 1087-1102.

Volk, S., Köhler, T., \& Pudelko, M. (2014). Brain drain: The cognitive neuroscience of foreign language processing in multinational corporations. Journal of International Business Studies, 45(7), 862-885.

Williamson, O. E. (2008). Outsourcing: Transaction cost economics and supply chain management. Journal of supply chain management, 44(2), 5-16.

Zhao, H., Luo, Y., \& Suh, T. (2004). Transaction cost determinants and ownership-based entry mode choice: A meta-analytical review. Journal of International Business Studies, 35(6), 524544. 
Table 1: A typology of entry mode deviations

\begin{tabular}{|c|c|c|}
\hline 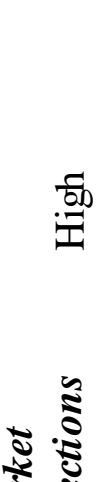 & $\begin{array}{l}\text { Deviating market mode } \\
\text { When market imperfectations are } \\
\text { high, deviant entry modes (e.g., } \\
\text { outsourcing, exporting) are associated } \\
\text { with: } \\
\text { - Hold-up situations } \\
\text { - Risk of opportunistic behavior and } \\
\text { - Inoral hazard }\end{array}$ & $\begin{array}{l}\text { Compliant hierarchical mode } \\
\text { When market imperfectations are } \\
\text { high, compliant entry modes (e.g., } \\
\text { wholly owned subsidiaries) are } \\
\text { asssociated with: } \\
\text { - Protection of firm assets } \\
\text { - Increased control } \\
\text { - Effective means of knowledge } \\
\text { transfer }\end{array}$ \\
\hline 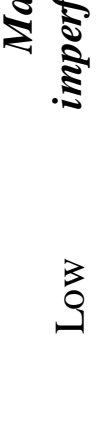 & $\begin{array}{l}\text { Compliant market mode } \\
\text { When market imperfections are low, } \\
\text { compliant entry modes (e.g., } \\
\text { outsourcing, exporting) are associated } \\
\text { with: } \\
\text { - Lower costs } \\
\text { - Access to external knowledge } \\
\text { - Benefits of large-n suppliers }\end{array}$ & $\begin{array}{l}\text { Deviating hierarchical mode } \\
\text { When market imperfections are low, } \\
\text { deviating entry modes (e.g., wholly } \\
\text { owned subsidiaries) are associated } \\
\text { with: } \\
\text { - Risk of inefficiency trap } \\
\text { - Learning my opia } \\
\text { - } \quad \text { N-I-H syndrome }\end{array}$ \\
\hline & 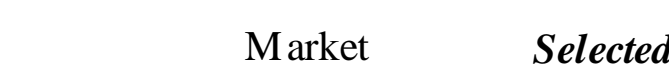 & Hierarchy \\
\hline
\end{tabular}


Table 2: Past performance and entry mode deviations

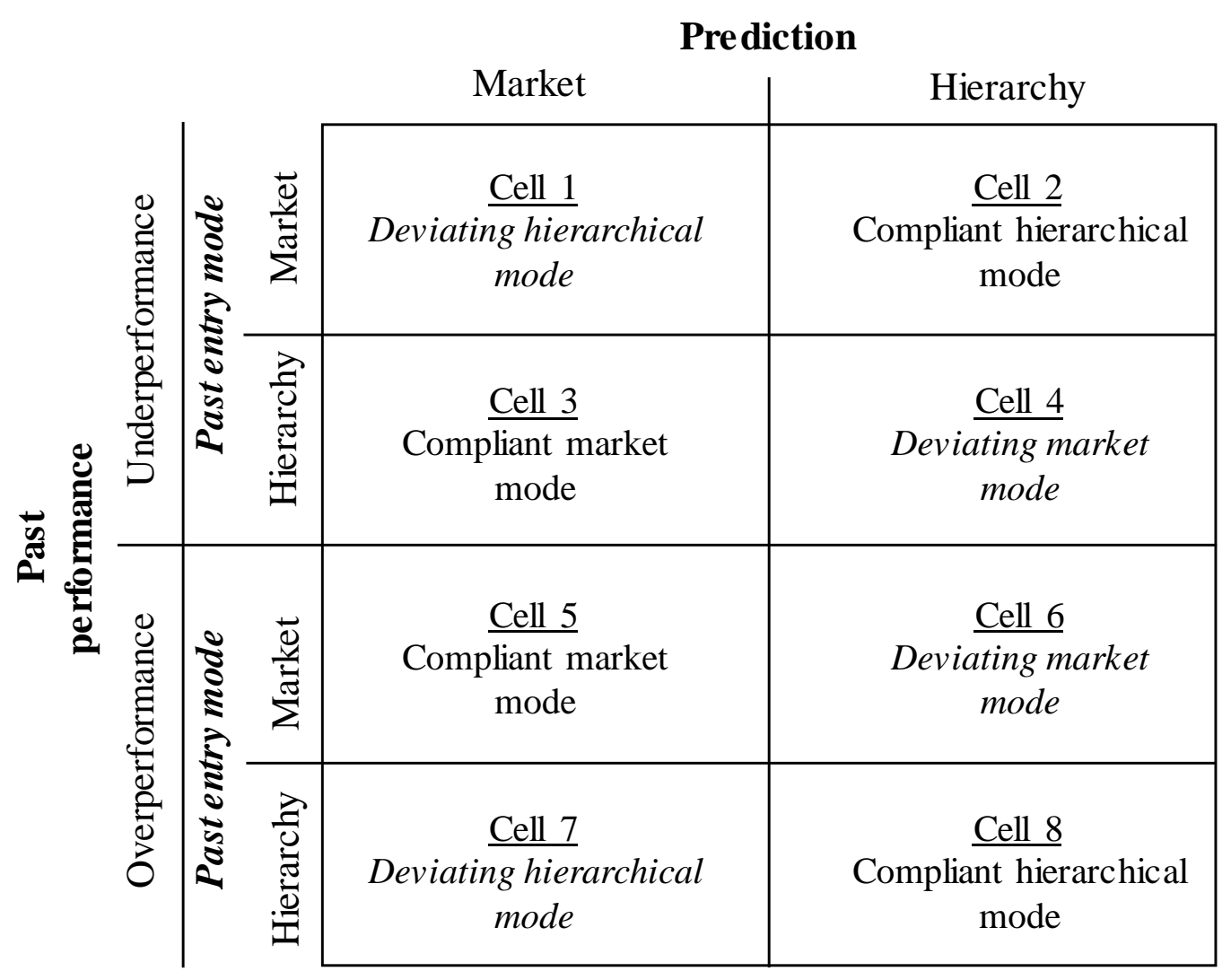

